\section{MICRO-ANALYSIS IN MEDICAL BIOCHEMISTRY}

By F. J. KING and I. D. P. Wotron. Third Edition. Pp. 292. London: J. \& A. Churchill Ltd. 1956. 22s. 6d.

Five years have passed since the second edition of this book appeared, and Professor King now shares the authorship with his colleague at the Postgraduate School, Dr. Wotton. Many changes have been made in the text. There is a new section on Normal Values and on the Control of Laboratory Accuracy which is particularly interesting, including as it does an indication of the variations to be expected in estimations and their type of distribution. (One cannot help wondering, after reading this, if the authors are justified in giving such precise limits for normal values elsewhere in the text, as for instance, on page 42 , where the normal plasma cholesterol is said to lie between $\mathrm{r} 53$ and $260 \mathrm{mg}$./100 $\mathrm{ml}$. !)

Reference to the use of the Duboscq type of colorimeter has been omitted, and it is everywhere assumed that photo-electric absorptiometers are being used; it is surprising, therefore (particularly after the brief mathematical approach to the problem of variation) to find that directions are given under each method for calculating the concentration of the unknown from the reading of a single standard. To assume that Beer's Law is universally valid (even for such a wayward substance as creatinine) seems to be unjustified. In any case, most laboratories are probably in the habit of constructing, and frequently checking, calibration curves.

Many new and valuable methods are included, and there are new sections on the techniques of metabolic balance studies, of radioisotope studies and of flame photometry. In the last case, the details given apply to the E.E.L. flame photometer but the instructions given for the concentrations of the standards do not appear to be the ones most convenient for this instrument. In dealing with potassium estimations it seems important to stress the need for avoiding haemolysis, since this is such a common source of error. The section on Renal Clearance Techniques now includes the method of Roe, Epstein and Goldstein for Inulin, a welcome addition, but is unorthodox in advocating trichloacetic acid precipitation of plasma proteins, instead of cadmium hydroxide, in the estimation of P.A.H.

Other minor criticisims might be made, but the book remains an important guide for everyone instrested in clinical biochemistry.

\section{A THERAPEUTIC INDEX}

By C. M. Miller and B. K. Elleenbogen. Second

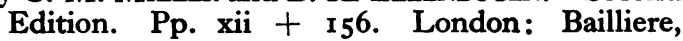
Tindall and Cox. 1956. 12s. 6d.

The second edition of this little book appears ex:actly two years after the first, and includes new information on Addison's Disease and the use of Cortisone besides a number of other additions.

It is too small, however, for the treatments described to be given in anything but outlines, and it is difficult to see how anyone could make use of these except as reminders of dosage details in an emergency. Surely not many doctors are as desperately busy as this type of publication would imply!

\section{A COMPANION IN SURGICAL STUDIES}

By IAN AIRD, Ch.M., F.R.C.S. 2nd edition. Pp. xii + 1,302. Edinburgh: E. \& S. Livingstone Ltd. r 957 . $f 44$ s. od.

It is difficult to review a new edition of probably the best 'standard' text book of general surgery. Perhaps some of the comments are not in strict accord with ' the latest work,' but apart from this being impossible in a text book with so wide a coverage, the essential basis upon which sound practice stands is all there. The presentation may be criticised for having too few illustrations, "too academic' an arrangement, too much this or too little that, but the reviewer, who has used the previous edition so often, is in complete sympathy with Professor Aird's statement in the introduction that the finest medium for communication is language, at least in so far as the written word can convey meaning. The omission of orthopaedics, whose printed exposition requires so much in the way of illustration, and which in any case is becoming further and further removed from ' general surgery,' cannot be criticized: similarly, the close proximity of the fields of thoracic and neuro surgery to the acres of general surgery, require a survey of each which, albeit not particularly deep or widespread, serves admirably the author's purpose to present points of contact and their interdependence in so many ways.

Whether the reduction in size of the chapter on Congenital Earpit is a good or bad thing remains to be seen, but there is no doubt that the original was an excellent example of literary technique.

The Publishers are to be congratulated again on their production, eminently readable, at the upper limits of size and, most commendable of all, not on shiny paper.

There cannot be a better recommendation of this book than to state that this must be THE standard text book of surgery.

A.E.C.

\section{BRITISH MEDICAL BULLETIN}

Symposium on Physiology and Pathology of the Kidney

Vol. 13, No. 1. Pp. 74, with 12 plates. London: The British Council. 1957. £ir.

Professor Robert Platt acted as Chairman of the Committee responsible for this admirable number of the British Medical Bulletin, and Professor Clifford Wilson was the Scientific Editor. There are 26 
other contributors, who come from London, Cambridge, Manchester, Birmingham, Portsmouth and Belfast - $a$ fair indication of the very widespread interest and activity in the field of renal disease in this country, though it is perhaps a pity that only the London Hospital and the Postgraduate Medical School represent the London centres.

Many of these articles are of great interest and provide authoritative up-to-date reviews of recent work not readily available elsewhere (for example, 'Potassium Deficiency and the Kidney,' by Milne, Muehrcke and Heard, and 'The Volume Control of Body-Fluids' by Oliver Wrong). The sections on 'Azotaemic Renal Osteodystrophy' (Stanbury), 'Renal Angiography' (Murray and Tresidder) and 'Venography in Relation to the Kidney' (Steiner) are also outstanding contributions which are, in addition, most beautifully illustrated. All the illustrations are excellently reproduced.

It is possible to do justice to this remarkable publication in a brief review; it is recommended without qualification to everyone interested in any aspect of renal function and renal disease. The price is so reasonable that a large number of those interested will be able to buy it.

\section{CONTEMPORARY RHEUMATOLOGY}

Proceedings of the Third Rheumatology Congress;

The Hague-Scheveningen. 1955. Edited by

J. Goslings, and $H$. van SwaAy. Pp. xix +

683, illustrated. London: Cleaver-Hume Press

Ltd. 1956. 95 s.

This well-produced book is the official record of the more important papers read at the Rheumatology Conference in Holland in 1955 . The papers are in English, French, Spanish and German, and are divided into sections on rheumatic fever, connective tissue, disc degeneration and osteoarthritis of the spine, rheumatism and social medicine and 'free subjects.' Summaries in English are present in almost all papers read in other tongues. It is invidious to pick out special papers for comment from such a large number, but the section on connective tissue changes in rheumatic diseases is particularly worthy of close attention. This book is a well-produced and well-edited cross section of what was a most interesting and instructive conference.

F.D.H.

\section{RHEUMATOID ARTHRITIS AND PSORIASIS VULGARIS}

By T. Beneder, M.D. Pp. xii +308 , with 56 illustrations. Chicago: Chicago Medical Book Co. 1955. \$12.

This is a personal book for Dr. Benedek sets out in it his view that common skin diseases like pompholyx, pityriasis rosea, seborrhoeic dermatitis and psoriasis amongst others are caused by a specific organism, and that the same organism also is the cause of rheumatoid arthritis in its peripheral and spinal form. The organism, which was found in a vesicle of pompholyx in 1927 is a "permanent endoparasite' of man and produces the various diseases by bacterial-allergic reactions. A vaccine has been prepared and good results are derived fromo its use. Although the evidence is presented and analysed in this monograph its publication does not appear to have been followed by a general acceptance of the author's concepts.

M.F.

\section{HOW TO GET THERE}

An Address Book for the Medical profession, showing how to reach the various Colleges, Societies, Institutes and Hospitals in or near London

New (Fourth) Edition: 1954

Price 2s. 6d. (2s. 10d., post free)

Published by the

\section{FELLOWSHIP OF POSTGRADUATE MEDICINE}

60 Portland Place, London, W.I 